Trivent Publishing

(C) The Authors, 2016

Available online at http://trivent-publishing.eu/

Philosophy, Communication, Media Sciences Series

Volume The Modern and Contemporary Reception of Saint Gerard of Cenad

\title{
Considerations Regarding the Intellectual Background of the Bishops of Cenad in the Middle Ages up to the Year 1526
}

\author{
Răzvan Mihai Neagu
}

Turda Technical College, Romania, neagurazvan10@yahoo.com

\begin{abstract}
The present study aims to prove that the bishops of the dioceses in Eastern Medieval Hungary were men of notable culture acquired in the great European universities of the time. The knowledge they acquired was of scholastic and eventually humanist nature, two specific trends of that epoch. The fact that some of the prelates had undertaken academic studies was to be a catalyst to their social and ecclesiastic ascension, which culminated with the ownership of the bishopric. Up to 1526, seven bishops of Cenad had academic studies. The most attended universities were those on the Italian Peninsula, especially Bologna and Padua. This situation accounts to the relative closeness to Rome, the religious centre of the Catholic world, as well as to the specialization in canon law of the Italian universities, to their fame, and to the strong bounds between Italy and Hungary, especially during the times of Matthias Corvinus. It is important to consider that these academic studies were a major factor which contributed to the religious and secular ascension of ecclesiastical personalities. Some of the bishops were notable humanists, decisively contributing to the outspread of the Renaissance ideas and spirit throughout Hungary. The activity of these academic bishops placed the ecclesiastic life of Hungary in the European pattern of the epoch.
\end{abstract}

\section{Keywords:}

Cenad; bishop; diocese; university; Humanism. 


\section{Preliminaries}

The present study aims to prove that the bishops of Cenad from the medieval period were people of great learning, educated in the most important European universities of the time. The knowledge they acquired was of scholastic and eventually humanistic nature, two specific trends of the epoch. The fact that some of the prelates had undertaken academic studies was a catalyst to their social and ecclesiastic ascension, culminating with the ownership of the bishopric.

Gratian's Decree, the main source of the medieval canon law, presented in the $12^{\text {th }}$ century the description of the ideal bishop. According to this document, the hierarch had to have a faultless behaviour (sine crimine), to be serious, balanced, hospitable, capable of learning, to abstain from alcohol, to avoid involvement in scandals, not to show interest in material goods, but to be able to lead his own household. Equally, a bishop had to be moderate, abstinent and a pacifist spirit, generous and learned. ${ }^{1}$ Referring to the nomination of a bishop, there were two procedures in use in the Middle Ages: the election inside the cathedral chapter and direct nomination from Rome.

The Third Council of Lateran (1179), dominated by the figure of Pope Alexander III, brought important specifications with reference to the prototype of the candidate to the bishopric. These council regulations can be summed by the formula aetatis maturitas et morum gravitas et scientia litterarum. The minimal age was 30 and the candidate to bishopry had to be of legitimate birth. ${ }^{2}$ Among the terms, literacy is highlighted, which will gain new valences together with the development of the European university phenomenon. Beginning with the end of the $12^{\text {th }}$ century and especially in the $13^{\text {th }}$ century, the Western Catholic bishops start attending the major European univeristies, their education determining their ecclesiastic careers. Peter Lombard, bishop of Paris (1158-1160), studied in Bologne, Reims, and Paris. His successor, Maurice de Sully (1160-1196), asserted himself as a keen theologian having studied at the University of Paris. The relationship between the professor and his student was long-lasting, persisting after the graduation. Here we mention Peter of Corbeil, Lothario, the count of Segni's Theology professor at the University of Paris. The disciple, who later became Pope Innocent III, did not forget his master and presented him with the bishopric of Cambrai (1199) and later with the archbishopric of Sens (1200). ${ }^{3}$ The bishop of Chartres, Peter of de Mincy (1260-1276), was doctor in utroque of the University of Paris. ${ }^{4}$ A thorough university education was claimed by the presence of the Cathar heretics for the dioceses of the South of France. Thus, Peter of La Chapelle Taillefer, bishop of Carcassonne (1291-1298) and later bishop of Toulouse (1298-1305), had a profound juridical preparation at the University of Orléans. ${ }^{5}$ The bishops' university preparation expanded from France to the Italian Peninsula, Iberian Peninsula, the British Isles, and later to the whole of Europe and eventually to Hungary.

\footnotetext{
${ }^{1}$ Jean Gaudemet, Le Gouvernement de l'Eglise a l'Époque classique, II'e partie Le Gouvernement Local (Paris: Cujas, 1979), 46.

${ }^{2}$ Wilfried Hartmann, Kenneth Pennington, The History of Medieval Canon Law in the Classical Period 11401234. From Gratian to the Decretals of Pope Gregory IX (Washington: The Catholic Universty of America Press, 2008), 335.

${ }^{3}$ Jean Gaudemet, Le Gouvernement de l'Eglise..., 93.

${ }^{4}$ The sintagm doctor in utroque shows that the person bearing this title was a doctor both in civil and canon law.

5 Jean Guademet, Le Gouvernement de l'Eglise..., 94.
} 


\section{The bishops of Cenad with university education up to 1526}

From a chronological perspective, the bishopric of Cenad is the first one registered in Banat and Transylvania. Its foundation is linked to the name of the first Christian king of Hungary, Saint Stephen I (997-1038), who appointed as bishop the Benedictine monk Gerardo Sagredo, of Italian origin. ${ }^{6}$ The historian Gyula Kristó noticed that apart from the bishopric of Pécs, that of Csanád was the only other diocese whose foundation can be linked to an exact date. A Hungarian annal (Annales Posonienses) contains the information that Gerard was ordained bishop in 1030. Since Gerard (Gellért) was the first prelate of the bishopric of Csanád, there can be little doubt that 1030 was also the year the bishopric of Csanád was founded. ${ }^{7}$ According to the papal tithe records between 1332 and 1337, the bishopric of Cenad was comprised of the following archdeaconships: Timiş, Arad, Cenad, Torontal, Caransebeş, Caraş, and the archdeaconship across river Mureş. ${ }^{8}$ In the Middle Ages, the bishopric of Cenad was comprised of extended areas from the South-East of Hungary which today belong to Romania, Serbia and Hungary. From a canonical point of view, the bishop of Cenad was the suffragan of the archbishop of Kalocsa, together with the bishops of Transylvania, Oradea, Zagreb, Bács, Bosnia, and Sirmium.

This study represents a sequel of our scientific work related to the intellectual background of the bishops in medieval Eastern Hungary, up to the battle of Mohacs (1526). Before developing this study, we wrote two other materials regarding the university training of the bishops of Transylvania and Oradea, which are to be published in Cluj-Napoca and Alba Iulia. The data we have on the bishopric of Cenad is much poorer than for the ones of Transylvania and Oradea. However, we will try to state some facts, in order to offer the picture of the intellectual formation of the bishops serving in this diocese in the medieval period. Data shows that the first bishop of Cenad with university studies was Thomas of Telegd (1350-1358). ${ }^{9}$ He was appointed on the $31^{\text {st }}$ of May 1350 by Pope Clement VI -- until then, Thomas was the provost of the church of Esztergom ${ }^{10}$ and a confidant of the royal court and the papacy of Avignon. It is known that he studied at a university in Italy and he obtained his doctor's degree in canon law, because on the $31^{\text {st }}$ of July 1349, while being the provost of Esztergom, he is mentioned as "Thomas decretorum doctor, auditor sancti palatii domini papae, vicarious generalis." 11 Thomas was the nephew of Telegdi Csanád, the archbishop of Esztergom, with whose support he became a member of the archbishop's chapter. ${ }^{12} \mathrm{He}$ had a

\footnotetext{
${ }^{6}$ Şerban Turcuş, Saint Gerard of Cenad. The Destiny of a Venetian around the Year One Thousand (ClujNapoca: Romanian Cultural Institute, Center for Transylvanian Studies, 2006).

${ }^{7}$ Kristó Gyula, The Bishoprics of Saint Stephen, king of Hungary in In honorem Paul Cernovodeanu, ed. Violeta Barbu (Bucharest: Kriterion, 1998), 62.

${ }^{8}$ Documente privind istoria României, seria C Transilvania, veacul XIV, vol. III (1331-1340) [Documents regarding the Romanian history, series C Transylvania, XIV century, vol. III 1331-1340] (Bucharest: Editura Academiei Republicii Populare Române, 1954), 221-247.

${ }^{9}$ Engel Pál, Magyarország Világi Archontológiája 1301-1457 [The Secular Archontology from Hungary] [CDROM], (Budapest: Arcanum, 2001), (henceforth Magyarország Világi Archontológiája).

${ }^{10}$ Ioan Haţegan, Ligia Boldea, Dumitru Țeicu, Cronologia Banatului, vol. 2, part 1: Banatul între 934-1552: repere cronologice: selecţie de texte şi date [The Chronology of Banat: Banat between 934-1552: chronological landmarks: selection of texts and data] (Timişoara: Banatul, 2007), 90.

${ }^{11}$ Schematismus cleri Diocesis Csanadiensis. Pro Anno Jubilari MDCCCC (Temesvárini 1900), 36; Veress Endre, Olasz Egyetemeken Járt Magyarországi Tanulók Anyakönyve és Iratai 1221-1864 [The Matriculation Register and Study Documents of Hungarian Students who Learned at Italian Universities 1221-1864] (Budapest: Magyar Tudományos Akadémia, 1941), 395.

12 Árpád Bossányi, Regesta Supplicationum. A Pápai Kérvénykönyvek Magyar Vonatkozásu Okmányai Avignoni Korszak, I. Kötet, VI. Kelemen Pápa 1342-1352[Regesta Supplicationum. The Hungarian Related Documents of
} 
brilliant ecclesiastic career, in 1341 he became archdeacon of Nitra, in 1342 he was a lecturer of the cathedral chapter in Esztergom, provost of the chapter, bishop of Cenad, archbishop of Kalocsa (1358-1367), and archbishop of Esztergom (1367-1376), Hungary's chancellor. ${ }^{13}$

After moving Thomas to the archbishopric of Kalocsa, the bishopric of Cenad remained vacant from April to September 1359, when Gregory III of Lendava (today's Slovenia) was appointed. He shepherded the diocese of Cenad for a very short time (1359-1360). ${ }^{14} \mathrm{He}$ is known to have studied at the University of Bologna where he received his doctor's degree in canon law. ${ }^{15}$ Gregory started his ecclesiastic career in the diocese of Oradea where he was a prebendary and custodian of the chapter. He fulfilled a series of diplomatic missions in Italy for King Louis I of Anjou, related to the Hungarian-Venetian conflict. In 1359 he was appointed bishop of Cenad, but he died in $1360 .{ }^{16}$

The next bishop of Cenad with university degree is mentioned only in the $15^{\text {th }}$ century, namely Ladislaus Marczali (1423-1434). ${ }^{17}$ He came from an illustrious family of medieval Hungary, being the nephew of the previous bishop, Dominic Marczali (1403-1423). Ladislaus was the son of the Transylvanian voivode Nicholas Marczali (1402-1403). ${ }^{18}$ He studied at the University of Vienna where he was registered in $1417 .{ }^{19}$ Before becoming a bishop, he held the dignity of provost of the cathedral chapter in Cenad. ${ }^{20}$

Albert of Hangach (1457-1466), coming from a family from Borsod county, had a special university training. He studied at the Universities of Vienna (1439), Padua (1449), and Bologna (1451), at the last one also receiving the title of doctor in canon law. Albert had an outstanding career from both an ecclesiastic and lay point of view. Thus, he was a chancellor (1443) and he took part in the crusade of Varna together with John Hunyadi where they were defeated by the Ottoman Turks. His ecclesiastic career summed the positions of: prebendary at Eger (1443-1445), provost at Pécs (1445-1456), provost of Eger (1456-1457), from this last position being appointed bishop of Cenad. ${ }^{21}$

the papal Books of Petitions in the Avignon Period, vol. I, Pope Clement VI 1342-1352] (Budapest: Stephaneum Nyomda, 1916), 282.

13 Borovszky Samu, Csanád vármegye története 1715-ig [The History of the Csanád county until 1715] (Budapest: A Magyar tudományos Akadémia Palotájában, 1895), 105; Juhász Kálmán, A csanádi püspökség [The bishopric of Cenad] (Arad, 1927), 10; Petru Iambor, '’Nobilii din neamul Cenad (sec. XII-XVII)"’ [Nobles of the Cenad Family] in Acta Musei Napocensis 34/II (1997), 35; Markó László, A magyar állam fóméltóságai Szent Istvántól napjainkig [The Hungarian Head of State and Dignitaries from St. Stephan to Present Day] (Budapest: Helikon, 2006), 331.

${ }^{14}$ Magyarország Világi Archontológiája.

15 Sándor Tonk, Erdélyiek egyetemjárása a középkorban [Transylvanian University Men in The Middle Ages] (Bucharest: Kriterion, 1979), 232.

16 Samu Borovszky, Csanád vármegye története..., 356. For further information on Grigore's role in the Hungarian-Venetian conflict, see Răzvan Mihai Neagu, 'Conflictul dintre Ungaria si Veneţia pentru Dalmaţia în secolul al XIV-lea. Prezenţe transilvane"' [The Conflict between Hungary and Venice for Dalmatia in the XIV century. Transylvanian Presences] in Studia Varia in Honorem Professoris Panait I. Panait Octogenarii, ed. Andreea Atanasiu Croitoru (Constanţa: Editura Muzeului Marinei Romane, 2011), 59-70.

${ }_{17}$ Magyarország Világi Archontológiája.

${ }^{18}$ Schematismus cleri Diocesis Csanadiensis..., 38.

19 Koloman Juhász, 'Ladislaus Marczali und sein Bistum Tschanad 1423-1434', Römische Quartalschrift fur Christliche Altertumskunde und Kirchengeschichte, 52, (1957): 152; Sándor Tonk, Erdélyiek egyetemjárása..., 273; Anna Tüskés, Magyarországi Diákok a Bécsi Egyetemen 1365 és 1526 Között (Students from Hungary at the University of Vienna between 1365-1526) (Budapest, 2008), 100.

${ }^{20}$ Samu Borovszky, Csanád vármegye története..., 359.

${ }^{21}$ Konrad Eubel, Hierarchia Catholica Medii Aevi sive Sumorum Pontificum, S.R.E. Cardinalium Ecclesiarum Antistitum Series Ab Anno 1431 Usque Ad Annum 1503 Perducta E Documentis Tabularii Praesertim Vaticani Collecta, Digesta, Edita Per Conradum Eubel, (Regesburg: Monasterii Sumptibus et Typis Librariae 
The longest period in office in the diocese of Cenad during the $15^{\text {th }}$ century was that of the bishop John IV of Sokol (1466-1493), who shepherded for 27 years. ${ }^{22}$ He came from an important family from the Satu Mare County, with ownership in Banat. His father Peter was count of Timis (1463-1466) together with his brother Michael and ban of Macva (1459). ${ }^{23}$ John's career began in 1466 when he was named prebendary of Oradea, while the next year he was appointed bishop of Cenad. His family's welfare allowed John to benefit from quality higher education at the University of Bologna where on the $23^{\text {rd }}$ of April 1467 he received his doctor's degree in canon law. ${ }^{24}$ The policy of Bishop John IV of Sokol supported King Matthias Corvinus who in return treated him with constant benevolence. In 1484, he joined the Pauline Order. ${ }^{25}$

The first bishop of Cenad in the $16^{\text {th }}$ century was Nicholas II Csáky (1500-1514). ${ }^{26} \mathrm{He}$ was a learned hierarch who studied at the University of Padua between 1497 and1502. Nicholas was a confidant of the king of Hungary, Vladislaus II, who supported him in becoming a bishop. During his time, the Holy See approved the inclusion of the Cistercian abbey's lands from Igriş to the bishopric's possesion, in order to cope with the expenses of the anti-Ottoman fight. ${ }^{27}$ Nicholas II Csáky lost his life while being executed at Nădlac by the participants to György Dózsa's uprising (1514). ${ }^{28}$

Nicholas's follower at the bishopric of Cenad was Francis of Chahol (1514-1526), aged only 22 at the date of his appointment. He had studied law at the University of Bologna where he is mentioned in 1520. The Venetian ambassador at the court of the Hungarian King Louis II characterised the young hierarch as a learned man. ${ }^{29}$ Similarly to his predecessor, Francis of Chahol had a tragic death on the battle field at Mohács (on the $29^{\text {th }}$ of August 1526), while being the leader of the bishopric's banderium. ${ }^{30}$

\section{Final considerations}

In conclusion, the diocese of Cenad had, until 1526, seven bishops with university studies. Six of them studied at only one university, while one of them studied at three universities. Similarly to the other dioceses (those of Transylvania and of Oradea), most future bishops (six) chose Italian universities (Bologna and Padua). Two bishops of Cenad studied at the University of Vienna. This situation can be explained by the proximity to Rome, the religious centre of the Catholic world, by the specialization in canon law of the Italian universities, by

Regensbergianae, 1914), 124 (henceforth Hierarchia Catholica Medii Aevi II); Erik Fügedi, '’A XV. Századi magyar püspökök" [The XV century Hungarian Bishops] Történelmi Szemle VIII (1965): 488; Jakubinyi György, Romániai Katolikus, Erdélyi Protestáns és Izraelita Vallási Archontológia [The Catholic, Transylvanian Protestant and Israelite Religious Archontology from Romania] (Cluj-Napoca: Verbum, 2010) 120; Anna Tüskés, Magyarországi Diákok a Bécsi..., 153.

${ }^{22}$ Hierarchia Catholica Medii Aevi II, 124; Martin Roos, Die alte Diözese Csanád. Zwischen Grundlegung und Aufteilung. 1030 bis 1923. Teil 1: Von den Anfängen bis zum Ende der Türkenzeit. 1030-1718. (Szeged-Csanád, Groß-Betschkerek, Temeswar: 2009), 184.

${ }^{23}$ Ioan Haţegan, Pavel Chinezu [Pál Kinizsi] (Timişoara: Helicon, 1994), 131.

${ }^{24}$ Endre Veress, Olasz Egyetemeken Járt..., 51; Sándor Tonk, Erdélyiek egyetemjárása ..., 260.

${ }^{25}$ Costin Feneşan, 'Studenţi din Banat la universităţile străine până la 1552"' [Students from Banat at the Foreign Universities until 1552] Revista de Istorie 12 (1976), 1953.

${ }^{26}$ Hierarchia Catholica Medii Aevi II, p. 124.

${ }^{27}$ Costin Feneşan, Studenţi din Banat..., 1953.

${ }^{28}$ Samu Borovszky, Csanád vármegye története..., 366; Martin Roos, Die alte Diözese Csanád..., 200.

${ }^{29}$ Costin Feneşan, Studenţi din Banat..., 1953.

${ }^{30}$ Samu Borovszky, Csanád vármegye története..., 368; Martin Roos, Die alte Diözese Csanád..., 202. 
the prestige of these institutions, by the strong relationships between the Italian and the Hungarian space, especially during Matthias Corvinus' reign. According to the documents we studied, there is information on the academic titles eceived by four of the bishops of Cenad: Thomas of Telegd was decretorum doctor, Gregory III of Lendava was doctor in canon law, just like Albert of Hangach and John IV Sokol. We believe that the academic training of these ecclesiastic personalities represented a major factor in their religious and lay ascension. It is obvious that many of the bishops were outstanding humanists, and thus brought their contribution to the spread of the Renaissance ideas and spirit in Hungary, as well as in Banat and Transylvania. The activity of these bishops with university studies brought the Hungarian ecclesiastic life into the European pattern of the time.

\section{THE CHRONOLOGICAL LIST OF THE BISHOPS OF CENAD WITH UNIVERSITY EDUCATION} UNTIL 1526

\begin{tabular}{|l|l|l|l|l|}
\hline No. & Name of the bishop & University attended & Years of service & Academic degree \\
\hline 1 & Thomas of Telegd & Italian university & $\begin{array}{l}\text { Cenad (1350-1358) } \\
\text { Kalocsa (1358-1367) } \\
\text { Esztergom } \\
(1367-1376)\end{array}$ & decretorum doctor \\
\hline 2 & Gregory III of Lendava & Bologna & $\begin{array}{l}\text { Cenad } \\
(1359-1360)\end{array}$ & doctor in canon law \\
\hline 3 & Ladislaus Marczali & Vienna & $\begin{array}{l}\text { Cenad } \\
(1423-1434)\end{array}$ & doctor in canon law \\
\hline 4 & $\begin{array}{l}\text { Albert of Hangach } \\
(1457-1466)\end{array}$ & $\begin{array}{l}\text { Vienna } \\
\text { Padua } \\
\text { Bologna }\end{array}$ & $\begin{array}{l}\text { Cenad } \\
(1466-1493)\end{array}$ & doctor in canon law \\
\hline 5 & $\begin{array}{l}\text { John IV of Sokol }(1466- \\
1493)\end{array}$ & Bologna & $\begin{array}{l}\text { Cenad } \\
(1500-1514)\end{array}$ & $\begin{array}{l}\text { Cenad } \\
(1514-1526)\end{array}$ \\
\hline 6 & $\begin{array}{l}\text { Nicholas II Csáky } \\
\text { Padua }\end{array}$ & $\begin{array}{l}\text { Francis of Chahol }(1514- \\
1526)\end{array}$ & Bologna & \\
\hline 7
\end{tabular}

\section{References}

Borovszky, Samu. Csanád vármegye története 1715-ig [The History of the Csanád county until 1715]. Budapest: A Magyar tudományos Akadémia Palotájában, 1895.

Bossányi, Árpád. Regesta Supplicationum. A Pápai Kérvénykönyvek Magyar Vonatkozásu Okmányai Avignoni Korszak, I. Kötet, VI. Kelemen Pápa 1342-1352 [Regesta Supplicationum. The Hungarian Related Documents of the papal Books of Petitions in the Avignon Period, vol. I Pope Clement VI 1342-1352]. Budapest: Stephaneum Nyomda, 1916.

Documente privind istoria României, seria C Transilvania, veacul XIV, vol. III (1331-1340) [Documents regarding the Romanian history, series C Transylvania, Fourteenth century, vol. III, 1331-1340] Bucharest: Editura Academiei Republicii Populare Române, 1954.

Engel, Pál, Magyarország Világi Archontológiája 1301-1457 [The Secular Archontology from Hungary] [CD-ROM]. Budapest: Arcanum, 2001.

Eubel, Konrad. Hierarchia Catholica Medii Aevi sive Sumorum Pontificum, S.R.E. Cardinalium Ecclesiarum Antistitum Series Ab Anno 1431 Usque Ad Annum 1503 
Perducta E Documentis Tabularii Praesertim Vaticani Collecta, Digesta, Edita Per Conradum Eubel. Regesburg: Monasterii Sumptibus et Typis Librariae Regensbergianae, 1914.

Feneşan, Costin. 'Studenţi din Banat la universităţile străine până la 1552', [Students from Banat at the Foreign Universities until 1552] Revista de Istorie 12 (1976): 1945-1965.

Fügedi, Erik. "A XV. Századi magyar püspökök'" [The XV century Hungarian Bishops] Történelmi Szemle VIII (1965): 477-498.

Gaudemet, Jean. Le Gouvernement de l'Eglise a l'Époque classique, II'e partie Le Gouvernement Local. Paris: Cujas, 1979.

Ioan Haţegan. Pavel Chinezu [Pál Kinizsi]. Timişoara: Helicon, 1994.

Haţegan, Ioan, Ligia Boldea, Dumitru Țeicu. Cronologia Banatului, vol. 2, Partea 1: Banatul intre 934-1552: repere cronologice: selecţie de texte şi date [The Chronology of Banat: Banat between 934-1552: chronological landmarks: selection of texts and data]. Timişoara: Banatul, 2007.

Iambor, Petru. 'Nobilii din neamul Cenad (sec. XII-XVII)" [Nobles of the Cenad Family] in Acta Musei Napocensis 34/II (1997), 29-36.

Jakubinyi, György. Romániai Katolikus, Erdélyi Protestáns és Izraelita Vallási Archontológia [The Catholic, Transylvanian Protestant and Israelite Religious Archontology from Romania].Cluj-Napoca: Verbum, 2010.

Juhász, Kálmán. A csanádi püspökség [The bishopric of Cenad]. Arad, 1927.

Juhász, Koloman. 'Ladislaus Marczali und sein Bistum Tschanad 1423-1434.' Römische Quartalschrift fur Christliche Altertumskunde und Kirchengeschichte 52 (1957): 151-168

Kristó, Gyula. The Bishoprics of Saint Stephen, king of Hungary in In honorem Paul Cernovodeanu, ed. Violeta Barbu, 55-66 Bucharest: Kriterion, 1998.

Markó, László. A magyar állam fóméltóságai Szent Istvántól napjainkig [The Hungarian Head of State and Dignitaries from St. Stephan to Present Day]. Budapest: Helikon, 2006.

Neagu, Răzvan Mihai. 'Conflictul dintre Ungaria si Veneţia pentru Dalmaţia în secolul al XIV-lea. Prezenţe transilvane', [The Conflict between Hungary and Venice for Dalmatia in the XIV century. Transylvanian Presences] in Studia Varia in Honorem Professoris Panait I. Panait Octogenarii, ed. Andreea Atanasiu Croitoru, 59-70. Constanţa: Editura Muzeului Marinei Romane, 2011.

Roos, Martin. Die alte Diözese Csanád. Zwischen Grundlegung und Aufteilung. 1030 bis 1923. Teil 1: Von den Anfängen bis zum Ende der Türkenzeit. 1030-1718. Szeged-Csanád, Groß-Betschkerek, Temeswar: 2009.

Schematismus cleri Diocesis Csanadiensis. Pro Anno Jubilari MDCCCC. Temesvárini: 1900.

Tonk, Sándor. Erdélyiek egyetemjárása a középkorban [Transylvanian University Men in The Middle Ages]. Bucharest: Kriterion, 1979.

Turcuş, Şerban. Saint Gerard of Cenad. The Destiny of a Venetian around the Year One Thousand. Cluj-Napoca: Romanian Cultural Institute, Center for Transylvanian Studies, 2006.

Tüskés, Anna. Magyarországi Diákok a Bécsi Egyetemen 1365 és 1526 Között (Students from Hungary at the University of Vienna between 1365-1526). Budapest, 2008.

Veress, Endre. Olasz Egyetemeken Járt Magyarországi Tanulók Anyakönyve és Iratai 12211864 [The Matriculation Register and Study Documents of Hungarian Students who Learned at Italian Universities 1221-1864]. Budapest: Magyar Tudományos Akadémia, 1941. 
Hartmann, Wilfried, Kenneth Pennington. The History of Medieval Canon Law in the Classical Period 1140-1234. From Gratian to the Decretals of Pope Gregory IX. Washington: The Catholic Universty of America Press, 2008. 